\title{
Large Cell Neuroendocrine Carcinoma of Urinary Bladder; Case Presentation
}

\author{
Mesanenin Büyük Hücreli Nöroendokrin Karsinomu; Olgu Sunumu
}

\author{
Ayşegül SARI', Murat ERMETE' ${ }^{1}$, Canan SADULLAHOĞLU' ${ }^{1}$ Kaan BAL ${ }^{2}$, Ahmet BOLÜKBAŞI'
}

Department of ${ }^{1}$ Pathology and ${ }^{2}$ Urology, İmir Atatürk Training and Research Hospital, IZMIR, TURKEY

\begin{abstract}
Large cell neuroendocrine tumor of the urinary bladder is very rare. It is a type of neuroendocrine carcinoma that is morphologically different from small cell carcinoma.

This manuscript describes a 67 -year-old man who presented with hematuria. Ultrasonogrophic and computer tomography revealed a $5 \mathrm{~cm}$ mass in right posterolateral wall of the bladder that invaded perivesical tissue and he subsequently underwent transurethral resection. Microscopic examination showed a tumor with a sheet-like and trabecular growth pattern comprising necrotic areas which infiltrated the muscularis propria. Tumoral cells had coarse chromatin, prominent nucleoli, moderate amount of cytoplasm and immunohistochemically stained strongly positive with synaptophysin, chromogranin and CD56.
\end{abstract}

There are only few case reports of large cell neuroendocrine tumor of the urinary bladder so the biological behavior and the treatment protocol of these tumors are still obscure. Appropriate management protocols and prognostic estimation could be achived by the increased number of cases being reported. Therefore in a case of a poorly differentiated tumor in bladder, although rare, it is important to consider large cell neuroendocrine carcinoma in differential diagnosis.

Key Words: Neuroendocrine, Carcinoma, Large cell, Small cell, Urinary bladder

\begin{abstract}
ÖZ
Mesanenin büyük hücreli nöroendokrin tümörleri çok nadirdir. Bu tümörler küçük hücreli karsinomdan morfolojik olarak farklı olan ayrı bir nöroendokrin karsinom tipidir.

$\mathrm{Bu}$ makalede 67 yaşında hematüri nedeniyle başvuran erkek olgu sunuldu. Ultrason tetkiki ve bilgisayarlı tomogrofide mesane sağ posterior-lateral duvarda yaklaşık $5 \mathrm{~cm}$ çapında perivezikal alanı infiltre eden kitle izlendi ve hastaya transüretral rezeksiyon uyguland. Mikroskobik olarak tabakalar ve trabeküler tarzda büyüme gösteren, muskularis propriayı yaygın olarak invaze etmiş arada nekroz odakları içeren tümör izlendi. Tümör hücreleri kaba kromatinli, belirgin nükleollu, kısmen bol sitoplazmalı olup immunohistokimyasal olarak sinaptofizin, kromogranin, ve CD56 ile kuvvetli pozitif idi.
\end{abstract}

Mesanenin Büyük Hücreli Nöroendokrin Karsinomu'na ait çok az sayıda olgu rapor edildiğinden, bu tümörlerin biyolojik davranışları ve tedavi protokolleri henüz belirsizdir. Rapor edilen olgu sayısının artması uygun tedavi protokollerinin geliştirilmesine ve prognozlarının tahmin edilmesine katkı sağlayacağından mesanede kötü diferansiye bir tümör varlığında, nadir olarak izlense de büyük hücreli nöroendokrin karsinomu akılda tutmak önem kazanmaktadır.

Anahtar Sözcükler: Nöroendokrin, Karsinom, Büyük hücreli, Küçük hücreli, Mesane

old male patient with a diagnosis of LCNEC in the bladder transurethral resection material together with the relevant literatures.

\section{CASE REPORT}

A 67-year-old male patient presented at the urology outpatients with hematuria and was admitted when a tumor was observed in the junction of the bladder side wall and dome of the bladder on abdominal ultrasonography. The patient's personal history included chronic obstructive lung disease and congestive heart failure for 15 years. The abdominal computed tomography (CT) revealed a

Correspondence: Ayşegül SARI

İzmir Atatürk Eğitim ve Araștırma Hastanesi, Patoloji Bölümü,

IZMIIR, TURKEY

E-mail: aysegulakder@gmail.com Phone: +90 5325265215 
mass of $5 \mathrm{~cm}$ in the largest dimension on the lateral wall of the bladder in the right posterior area infiltrating the perivesical region and a $3 \mathrm{~cm}$ lymphadenopathy in the right iliac region. Thorax CT findings were within normal limits. Positron Emission Tomography and Computed Tomography revealed a hypermetabolic mass $6 \times 5 \mathrm{~cm}$ in size with irregular contours, filling the right half of the bladder and showing vegetative growth into the lumen. Cystoscopy and transurethral resection (TUR) was performed on the patient with these findings. All the TUR material $4 \mathrm{cc}$ in volume was evaluated and microscobic examination revealed a sheet-like and trabecular growing tumor that had diffusely invaded the lamina propria and muscularis propria with occasional necrotic foci (Figure 1). Tumor cells showed coarse chromatin, prominent large nucleoli, quite large cytoplasm cytoplasm, and were polygonal shaped with high mitotic activity (Figure 2). Synaptophysin (1:100 dilution, Neomarkers, FremontCA), chromogranin (1:200 dilusyon, Neomarkers, Fremont, CA), CD 56 (1:50 dilution, Neomarkers, Fremont CA), Cytokeratin 7 (1:100, Neomarkers, Fremont, CA), Cytokeratin 20 (1:50, Novocastra, UK), p63 (1:100, Neomarkers, Fremont, CA), TTF-1 (1:100 dilution, Novocastra, UK), PSAP(Neomarkers, Fremont, CA, PASEI415) and PSA (Neomarkers, Fremont, CA, Ab-1(ER-PR8)) stains were applied by using the streptavidin-avidin-biotin histochemical method and the Leica-Bond Max automatic immunostaining device.

Tumor cells were widespread positive with synaptophysin (Figure 3A), chromogranin, CD56 (Figure 3B) and CK 7 (Figure 4A) and focal positive with CK 20 and p63 (Figure 4B). High molecular weight cytokeratin, TTF-1, PSA and

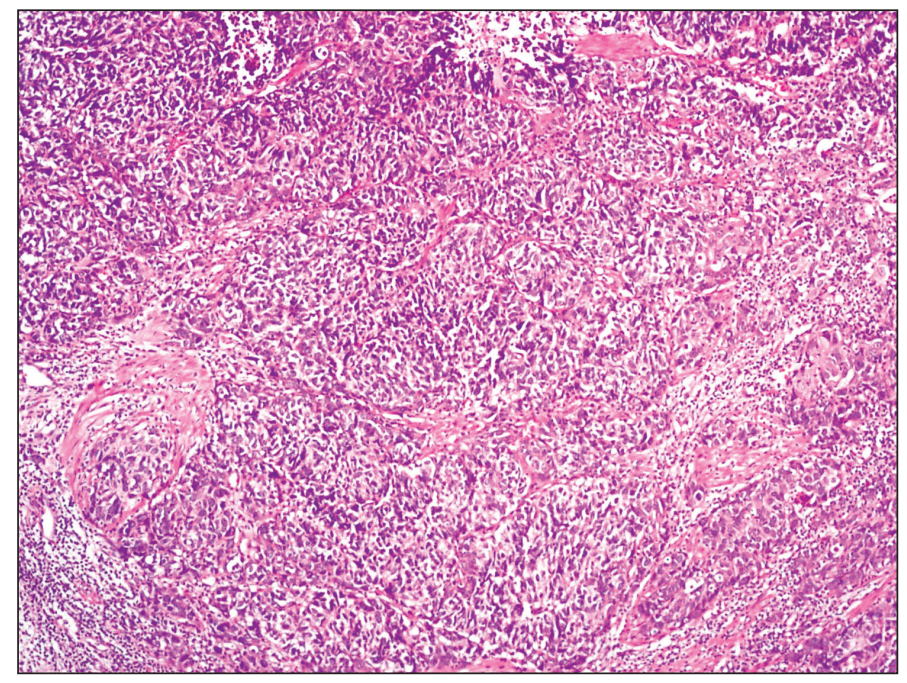

Figure 1: Tumor diffusely invaded the muscularis propria, showing sheet-like and trabecular growth (H\&E x100).

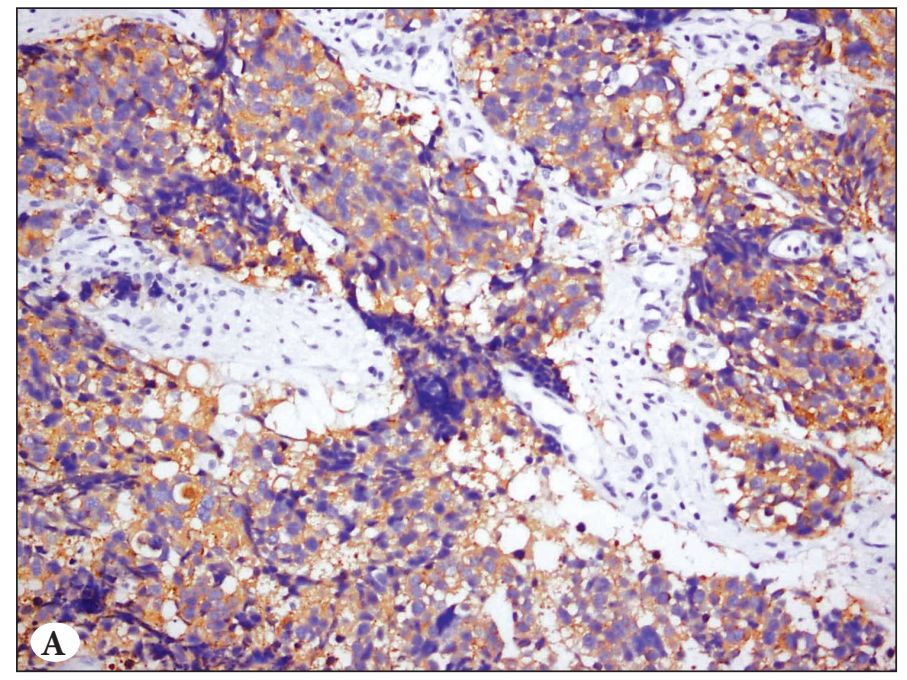

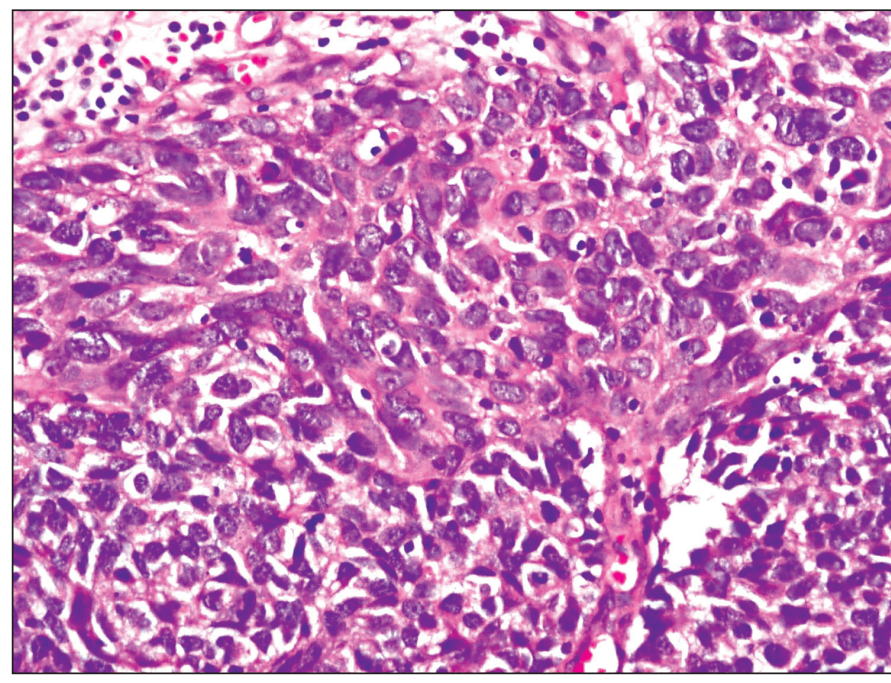

Figure 2: Large pleomorphic tumoral cells with active mitosis and pink or pale cytoplasm (H\&E x400).

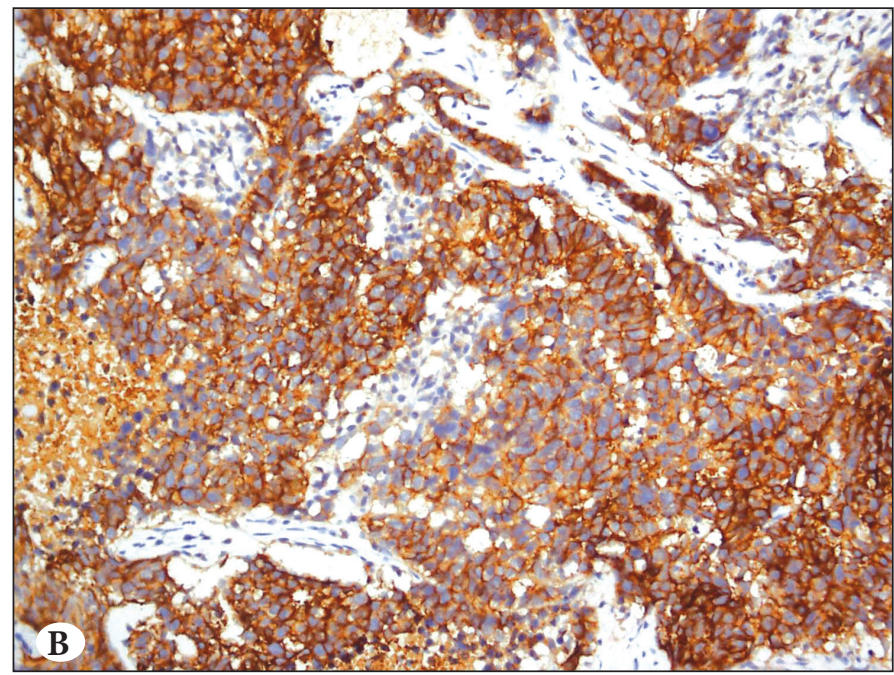

Figure 3: Tumor cells with (A) synaptophysin positivity (x200), (B) CD 56 positivity (x200). 
PSAP were negative. An accompanying conventional urothelial carcinoma (UC) area was not observed. The patient was diagnosed with LCNEC, pT2 and died of heart faiure two weeks after the TUR surgery.

\section{DISCUSSION}

The most common type of bladder NE tumor is SCC and makes up $0.5-0.7 \%$ of primary bladder tumors (3-5). Bladder SCC shows microscopic and immunohistochemical features similar to pulmonary SCC. SCC may be accompanied by urothelial, squamous or glandular differentiation (4). Most patients are in the advanced phase at diagnosis, and metastases develop within a short time. The second most frequent NE tumor of the bladder is carcinoid, and about 20 cases have been reported so far (6-9).

LCNEC of the bladder was first described by Aboza et al. in 1986 in a 55-year-old patient and was reported to be associated with adenocarcinoma (10). Only four of the 14 LCNEC cases reported so far has been in the pure form $(4,5,11)$ and other cases have been accompanied by adenocarcinoma, urothelial carcinoma, squamous cell carcinoma, carcinosarcoma, or lymphoepithelioma-like carcinoma $(2,3,10,12,13)$. Clinicopathologic findings of the reported cases are summarized in Table I. LCNED was observed in a pure form in the TUR material in our case, but we could not rule out the presence of an accompanying carcinoma since there is a possibility of residue tumor in the bladder.

The basic features of LCNEC in organs other than the lung such as the bladder, uterus, thymus, stomach, larynx, parotid gland, prostate and kidneys, are histologically similar to their counterpart in the lung (2). The large size, polygonal shape, low nuclear/cytoplasmic ratio, coarse chromatin structure and frequent nucleoli are the most important features of the cells. More than 10 mitosis in 10 high power fields and necrosis are often present $(2,4)$. Synaptophysin, chromogranin and CD56 positivity are present immunohistochemically. LCNEC observed in the lung have been classified as large cell carcinoma variant by the WHO as they show morphological similarity with nonsmall cell lung tumors. However, they are clinically similar to SCC with a very poor prognosis, and similar response to cisplatin-based therapy (2). As in the lung, bladder SCCs have a poor prognosis and 5-year survival is approximately $8 \%$ (3). Bladder LCNECs also have a rapid course and poor prognosis like SCCs $(3,5)$. Bladder LCNECs are very rare tumors so there is no specific treatment protocol but studies with pulmonary LCNECs show they respond well to standard chemotherapy regimens administered to SCCs $(14,15)$.

The etiology of bladder NE carcinomas has not been elucidated as yet. The most widely accepted hypothesis is that neuroendocrine cells develop from stem cells or multipotent undifferentiated cells in the urothelium. Another theory is that they develop from metaplastic urothelium or high grade urothelial carcinoma (3). One of the finding which supports this theory is that besides bladder SCCs more than \%50 of the bladder LCNECs are found to be associated with more differentiated cell forms such as urothelial carcinoma, and adenocarcinoma. The immunohistochemical heterogenity that both LCNEC and SCC show by staining with epithelial and neuroendocrine determinants to a certain degree also supports the multipotent stem cell theory (4). Although a conventional urothelial carcinoma area was not observed in our case, the positive staining of LCNEC areas with CK 7 and CK 20 (epithelial markers positive in urothelial carcinoma)
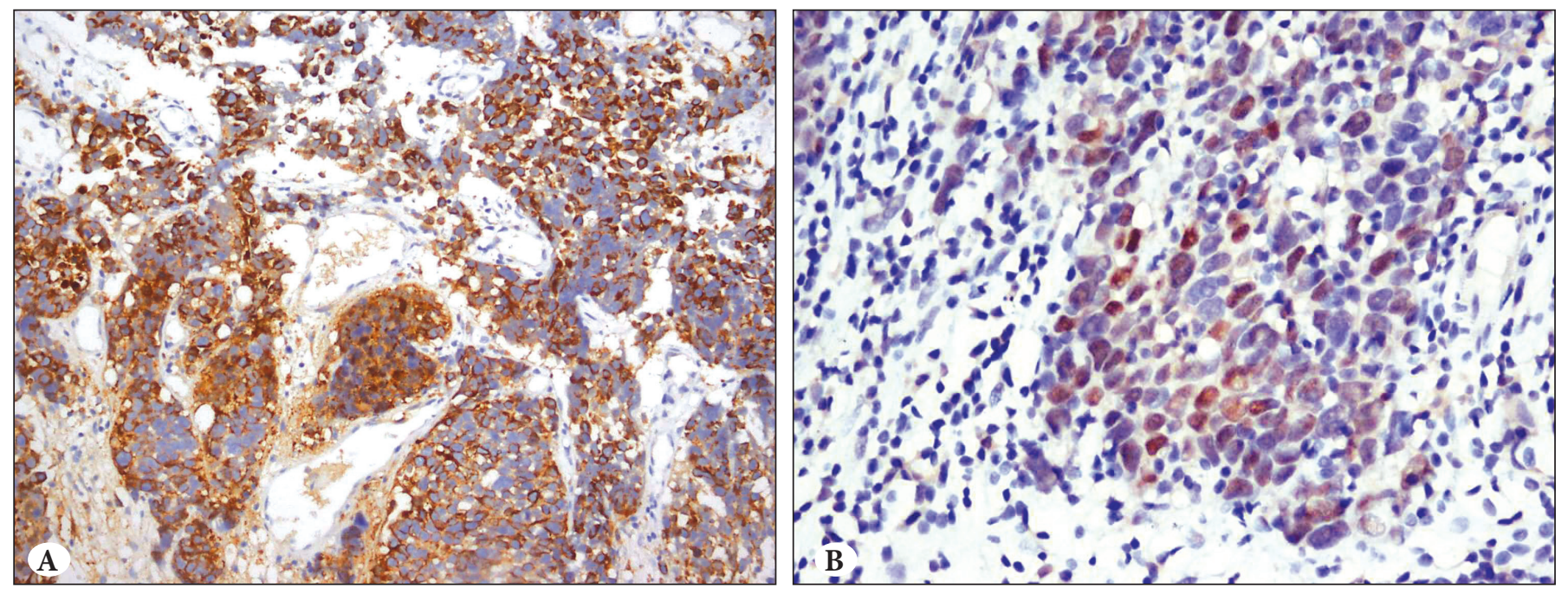

Figure 4: Tumor cells with (A) cytokeratin 7 positivity (x200), (B) P63 positivity (x400). 
Table I: Published cases of bladder large cell neuroendocrine carcinoma

\begin{tabular}{|c|c|c|c|c|c|c|}
\hline Reference & $\begin{array}{l}\text { Age/ } \\
\text { Gender }\end{array}$ & Symptom & Mix Histology & Surgery & Treatment & Follow-Up \\
\hline$(10)$ & $55 \mathrm{Y} / \mathrm{M}$ & $\begin{array}{l}\text { Hematuria } \\
\text { and Mucoid } \\
\text { changes }\end{array}$ & Adenocarcinoma & $\mathrm{RCx}$ & CT & $\begin{array}{l}\text { Died after } 30 \text { months of } \\
\text { follow up }\end{array}$ \\
\hline (11) & $73 \mathrm{Y} / \mathrm{M}$ & Hematuria & Pure & $\mathrm{RCx}$ & $\begin{array}{l}\text { Could not be } \\
\text { given as he was } \\
\text { immunosuppressed } \\
\text { for a renal transplant }\end{array}$ & $\begin{array}{l}\text { Died } 2 \text { months after the } \\
\text { surgery }\end{array}$ \\
\hline (3) & $82 \mathrm{Y} / \mathrm{M}$ & Hematuria & Adenocarcinoma & PRx & $\begin{array}{l}\text { CT } \\
\text { RT }\end{array}$ & $\begin{array}{l}\text { Alive without disease after } \\
2 \text { years of follow up }\end{array}$ \\
\hline (12) & $54 \mathrm{Y} / \mathrm{F}$ & $\begin{array}{l}\text { Hematuria } \\
\text { and } \\
\text { urethrargia } \\
\end{array}$ & $\begin{array}{l}\text { Lymphoepithelioma } \\
\text { like carcinoma + UC }\end{array}$ & $\mathrm{RCx}$ & CT & $\begin{array}{l}\text { Alive after } 16 \text { months of } \\
\text { follow-up with lymph } \\
\text { node metastasis, }\end{array}$ \\
\hline (13) & $61 \mathrm{Y} / \mathrm{E}$ & Hematuria & Carcinosarcoma & $\mathrm{RCx}$ & $\begin{array}{l}\text { No adjuvant } \\
\text { treatment }\end{array}$ & $\begin{array}{l}\text { Alive without disease after } \\
8 \text { months of follow-up }\end{array}$ \\
\hline (16) & \begin{tabular}{|l|}
$61-79 \mathrm{Y}$ \\
$4 \mathrm{M} \& 1 \mathrm{~F}$
\end{tabular} & NI & $\begin{array}{l}2 \text { cases PURE } \\
3 \text { cases UC }\end{array}$ & $\mathrm{NI}$ & $\mathrm{NI}$ & $\begin{array}{l}4 \text { cases died due to the } \\
\text { disease, } \\
1 \text { case alive after } 24 \\
\text { months of follow-up } \\
\end{array}$ \\
\hline (4) & $32 \mathrm{Y} / \mathrm{M}$ & Hematuria & Pure & $\mathrm{PCx}$ & CT & $\begin{array}{l}\text { Alive with lung and liver } \\
\text { metastasis after } 10 \text { months } \\
\text { of follow-up }\end{array}$ \\
\hline (5) & $\begin{array}{l}40 \mathrm{Y} / \mathrm{M} \\
28 \mathrm{Y} / \mathrm{F}\end{array}$ & NI & $\begin{array}{l}\text { Pure } \\
\text { Pure }\end{array}$ & $\begin{array}{l}\mathrm{RCx} \\
\mathrm{RCx}\end{array}$ & $\begin{array}{l}\text { CT } \\
\text { RT }\end{array}$ & $\begin{array}{l}\text { Alive with the disease after } \\
13 \text { months of follow-up } \\
\text { Died } 12 \text { months after the } \\
\text { surgery }\end{array}$ \\
\hline (2) & $63 \mathrm{M}$ & Hematuria & $\begin{array}{l}\text { Squamous cell } \\
\text { carcinoma and UC }\end{array}$ & $\mathrm{RCx}$ & CT & $\begin{array}{l}\text { Alive without disease } \\
\text { after16 months of follow- } \\
\text { up }\end{array}$ \\
\hline Our case & $67 \mathrm{Y} / \mathrm{M}$ & Hematuria & Pure & TUR & $\begin{array}{l}\text { RCx + CT were } \\
\text { planned }\end{array}$ & Died 15 days later \\
\hline
\end{tabular}

M: Male, F: Female, RCx: Radical Cystectomy, PRx: Partial cystectomy, CT: Chemotherapy, RT: Radiotherapy, TUR: Transurethral resection, NI: No information, UC: Urothelial carcinoma.

in addition to neuroendocrine markers is consistent with the multipotent cell theory. P63 is an urothelial carcinoma determinant and was focal positive in our case. Although this seems to support the theory that LCNEC develops from high-grade urothelial carcinoma, there is no information available in the literature regarding $\mathrm{p} 63$ positivity in bladder LCNECs. Buza N. et al showed all 14 of their SCC cases except one to be negative for $\mathrm{p} 63$ in a study they conducted on bladder SCCs. However, that study defined p63 positivity as at least $10 \%$ of the tumor cells showing staining (17). More studies are needed to determine the meaning and role of $\mathrm{p} 63$ positivity in the differential diagnosis of bladder neuroendocrine carcinomas.

It is important to differentiate bladder LCNEC from metastatic LCNEC originating from other organs, poorly differentiated prostate adenocarcinoma or lymphoma showing local extension, and primarybladder tumors such as high grade UC and squamous cell carcinoma. In the presence of a tumor morphologically similar to LCNEC that needs to be differentiated from high-grade, poorly differentiated UC, the presence of immunohistochemical positivity for neuroendocrine determinants supports LCNEC. The most 
significant histological features differentiating LCNEC from SCC with similar neuroendocrine characteristics are large cell size, prominent nucleoli, coarse chromatin, low nuclear/cytoplasmic ratio and trabecular organoid arrangement (2).

In conclusion, it is important to keep LCNEC in mind in the presence of a poorly differentiated tumor in the bladder as it has been reported that adjuvant chemotherapy, as well as surgical treatment can ensure long-term control in localized bladder LCNECs similar to pulmonary LCNECs (2). In addition, the increasing number of reported cases will contribute to the development of appropriate treatment protocols.

\section{REFERENCES}

1. Mazzucchelli R, Morichetti D, Lopez-Beltran A, Cheng L, Scarpelli M, Kirkali Z, Montironi R: Neuroendocrine tumours of the urinary system and male genital organs: Clinical significance. BJU Int 2009, 103:1464-1470

2. Akamatsu S, Kanamaru S, Ishihara M, Sano T, Soeda A, Hashimoto K: Primary large cell neuroendocrine carcinoma of the urinary bladder. Int J Urol 2008, 15:1080-1083

3. Evans AJ, Al-Maghrabi J, Tsihlias J, Lajoie G, Sweet JM, Chapman WB: Primary large cell neuroendocrine carcinoma of the urinary bladder. Arch Pathol Lab Med 2002, 126:1229-1232

4. Lee KH, Ryu SB, Lee MC, Park CS, Juhng SW, Choi C: Primary large cell neuroendocrine carcinoma of the urinary bladder. Pathol Int 2006, 56:688-693

5. Alijo Serrano F, Sanchez-Mora N, Angel Arranz J, Hernandez C, Alvarez-Fernandez E: Large cell and small cell neuroendocrine bladder carcinoma: Immunohistochemical and outcome study in a single institution. Am J Clin Pathol 2007, 128:733-739

6. Martignoni G, Eble JN: Carcinoid tumors of the urinary bladder. Immunohistochemical study of 2 cases and review of the literature. Arch Pathol Lab Med 2003, 127:e22-24

7. McCabe JE, Das S, Dowling P, Hamid BN, Pettersson BA: Oncocytic carcinoid tumour of the bladder. J Clin Pathol 2005, 58:446-447
8. Sugihara A, Kajio K, Yoshimoto T, Tsujimura T, Iwasaki T, Yamada N, Terada N, Tsuji M, Nojima M, Yabumoto H, Mori $Y$, Shima H: Primary carcinoid tumor of the urinary bladder. Int Urol Nephrol 2002, 33:53-57

9. Mascolo M, Altieri V, Mignogna C, Napodano G, De Rosa $G$, Insabato $L$ : Calcitonin-producing well-differentiated neuroendocrine carcinoma (carcinoid tumor) of the urinary bladder: Case report. BMC Cancer 2005, 5:88

10. Abenoza P, Manivel C, Sibley RK: Adenocarcinoma with neuroendocrine differentiation of the urinary bladder. Clinicopathologic, immunohistochemical, and ultrastructural study. Arch Pathol Lab Med 1986, 110:1062-1066

11. Hailemariam S, Gaspert A, Komminoth P, Tamboli P, Amin M: Primary, pure, large-cell neuroendocrine carcinoma of the urinary bladder. Mod Pathol 1998, 11:1016-1020

12. Dundr P, Pesl M, Povysil C, Vitkova I, Dvoracek J: Large cell neuroendocrine carcinoma of the urinary bladder with lymphoepithelioma-like features. Pathol Res Pract 2003, 199: 559-563

13. Li Y, Outman JE, Mathur SC: Carcinosarcoma with a large cell neuroendocrine epithelial component: First report of an unusual biphasic tumour of the urinary bladder. J Clin Pathol 2004, 57:318-320

14. Iyoda A, Hiroshima K, Moriya Y, Takiguchi Y, Sekine Y, Shibuya K, Lizasa T, Nakatani Y, Fujisawa T: Prospective study of adjuvant chemotherapy for pulmonary large cell neuroendocrine carcinoma. Ann Thorac Surg 2006, 82:1802-1807

15. Yamazaki S, Sekine I, Matsuno Y, Takei H, Yamamoto N, Kunitoh H, Ohe Y, Tamura T, Kodama T, Asamura H, Tsuchiya $\boldsymbol{R}$, Saijo $N$ : Clinical responses of large cell neuroendocrine carcinoma of the lung to cisplatin-based chemotherapy. Lung Cancer 2005, 49:217-223

16. Quek ML, Nichols PW, Yamzon J, Daneshmand S, Miranda G, Cai J, Groshen S, Stein JP, Skinner DG: Radical cystectomy for primary neuroendocrine tumors of the bladder: The university of Southern California experience. J Urol 2005, 174:93-96

17. Buza N, Cohen PJ, Pei Hui, Parkash V: Inverse p16 and p63 expression in small cell carcinoma and high-grade urothelial cell carcinoma of the urinary bladder. Int J Surg Pathol 2010, 18: 94-102 